УДК 336.26

\title{
ТОЧКИ ЗРОСТАННЯ ТА ЇХ РОЛЬ У ЗАБЕЗПЕЧЕННІ СТІЙКОГО ЕКОНОМІЧНОГО РОЗВИТКУ ТЕРИТОРІЙ
}

\author{
GROWTH POINTS AND THEIR ROLE \\ IN PROVIDING SUSTAINABLE ECONOMIC \\ DEVELOPMENT OF TERRITORRIES
}

\author{
Бондарук Таїсія Григорівна \\ доктор економічних наук, професор, \\ Державна установа «ннститут економіки та прогнозування \\ Національної академії наук України» \\ ORCID: https://orcid.org/0000-0001-9410-6428 \\ Bondaruk Taisiia \\ Institute for Economics and Forecasting \\ of the National Academy of Sciences of Ukraine
}

Досліджено теоретико-методичні засади фрормування точок зростання в контексті забезпечення стійкого економічного розвитку територій. Виявлено групи фракторів, які стримують ефрективну реалізацію фрорм активізації точок зростання. Запропоновано алгоритм організаційно-методичного інструментарію, активізації точок економічного зростання територій, який включає ряд етапів: визначення передумов активізації точок економічного зростання (виявлення особливостей розвитку території); виявлення фракторів, які впливають на активізацію точок економічного зростання території (забезпеченість трудовими, фрінансовими, бюджетними ресурсами); оцінка результативності розвитку вже існуючих точок економічного зростання (оцінка економічних показників та фрінансових результатів); аналіз ресурсних потенціалів територій; виявлення нових точок економічного зростання територій, потенційних полюсів інноваційного розвитку.

Ключові слова: точки зростання, потенціал території, активізація точок зростання, інноваційна діяльність, оцінка результативності, полюси інноваційного розвитку.

Исследованы теоретико-методические основы фрормирования точек роста в контексте обеспечения устойчивого экономического развития территорий. Выявлено группы фракторов, которые сдерживают эффрективную реализацию фрорм активизации точек роста. Предложен алгоритм организационно-методического инструментария активизации точек экономического роста территорий, включающий ряд этапов: определение предпосылок активизации точек экономического роста (выявление особенностей развития территории) выявление фракторов, влияющих на активизацию точек экономического роста территории (обеспеченность трудовыми, фринансовыми, бюджетными ресурсами) оценка результативности развития существующих точек экономического роста (оценка экономических показателей и фринансовых результатов); анализ ресурсных потенциалов территорий; выявление новых точек экономического роста территорий, потенциальных полюсов инновационного развития.

Ключевые слова: точки роста, потенциал территории, активизация точек роста, инновационная деятельность, оценка результативности, полюса инновационного развития.

The study investigated theoretical and methodical principals of growth points formation in the context of providing sustainable economic development of territories. It revealed the groups of factors, which control the effective implementation of forms of activation of growth points: regulatory (the lack of necessary regulatory acts for activating territorial growth points); organizational (ineffective infrastructure and insufficient use of forms of activation of territorial growth points); social (the lack of conditions for promoting the economic population activity and social direction territories development); financial (low opportunities for increasing the sources of financing, the lack of necessary significant financial flows); investment (small investment attraction of territories); innovative (the lack of effective mechanisms to stimulate the development of sphere of innovations); ecological (the lack of would-be possibilities to reduce the negative effect on natural environment). The study proposes the scheme of organizational and methodical set of instruments, the activation of economic growth points that include several stages: indicating the premises to activate the economic growth points (identifying the peculiarities of territories development, the analysis of restraining 
factors: regulatory, financial, social, investment, organizational, innovative, and ecological); revealing the factors that affect the activation of economic growth points of the territory (providing labour, financial, and budgetary resources, the effectiveness of economic development); the assessment of the effectiveness of the development of existing economic growth points (the assessment of economic indices and financial results), the analysis of the resources capabilities of territories (the analysis of the scientific and technical capabilities of territories, natural resources, the effectiveness of their use in the interests of the region, the provision of qualified personnel, the effectiveness of the use of economic methods to stimulate economic and innovative activities); revealing new economic growth points of territories, would-be sides of innovative development.

Keywords: growth points, the potential of the territory, activation of growth points, innovative activity, the assessment of the effectiveness, sides of innovative development.

Постановка проблеми. Економічний розвиток територій, який на сьогодні характеризуються процесами фрормування поляризованого економічного простору, актуалізує значення окремих точок економічного зростання як найважливіших детермінант динамічного розвитку територій. Активізація точок економічного зростання територій $є$ необхідним процесом, що дозволяє сконцентрувати обмежені ресурси в межах окремої території, створюючи джерела інновацій в економічній, технологічній, соціальній та управлінській сорерах і забезпечуючи максимальний і тривалий економічний ефект.

В сучасних умовах функціонування вітчизняної економіки, з урахуванням специфіки розвитку територіальних громад стає очевидною необхідність пошуку місцевих ключових можливостей за допомогою яких можна вирішити комплекс проблем місцевого економічного розвитку. Посилення впливу глобальної конкуренції $€$ передумовою до модернізації тактичних і стратегічних заходів регіональної політики, та впровадження інноваційних інструментів політики регіону, яка визначає зростання значущості виявлення точок економічного зростання в регіонах. В умовах децентралізації, коли приділяється значна увага проблематиці соціально-економічного розвитку територіальних громад, стає очевидним необхідність виявлення і розвитку точок економічного зростання.

Забезпечення стійкого економічного розвитку територій в умовах формування процесів пов'язаних з проведення реформи децентралізації в Україні, які характеризуються тим, що традиційні чинники економічного зростання, які забезпечували соціально-економічний розвиток територій практично вичерпані, на сьогодні гостро стоїть проблема пошуку нових джерел зростання, що актуалізує проблеми визначення точок зростання територій, економіка яких значною мірою самостійно повинна забезпечити вирішення завдань їх комплексного розвитку. Тому особливої уваги потре- бує перегляд сорормованих раніше пріоритетів економічного розвитку територій, зокрема сфрормованих профрілюючих видів економічної діяльності, які на сьогодні не можуть забезпечити ефрективного фрункціонування економіки териториальних громад, а також пошук нових точок економічного зростання, в контексті забезпечення стійкого економічного розвитку територій.

Метою статті $€$ поглиблення теоретикометодичних засад формування точок зростання в контексті забезпечення стійкого економічного розвитку територій.

Аналіз останніх досліджень і публікацій. Проблема стійкого економічного розвитку та фрормування процесів прискореного економічного зростання залишаються предметом наукових досліджень багатьох учених. Теорії кумулятивного зростання i, зокрема, моделі полюсів зростання досліджували такі відомі вчені як Ф. Перру, Ж.-Р. Будвіль, Х. Р. Ласуен; теорії просторового розвитку та, зокрема, моделі зростання міських агломерацій Х. Річардсон, Дж. Фрідман та ін.

Так, фрранцузький учений Ф. Перру [1] в роботі «Економіка $X X$ століття» загальну економічну теорію розподіляє: на 1) теорію домінуючої економіки, яка має дати характеристику сучасної економіки держави; 2) теорію гармонізованого зростання, яка вказує шляхи і методи ії удосконалення за допомогою державного регулювання; 3) теорію загальної економіки, яка характеризує суспільство майбутнього, в якому виробництво здійснюється для кожної людини.

Ф. Перру [2] вперше запропонував терміни «полюс зростання» і «центр розвитку». Під полюсами зростання він розумів компактно розміщені галузі промисловості чи окремі підприємства, що динамічно розвиваються, та в яких зосереджений своєрідний «імпульс розвитку», котрий позитивно впливає на територіальну структуру господарства та на їі динаміку [2]. Такий позитивний вплив відбувається в результаті концентрації інших підприємств чи галузей, 
що формуються та групуються навколо галузі, в якій зосереджений «імпульс розвитку». Якщо ця галузь $€$ і пропульсивною, тобто здатна надавати позитивний мультиплікаційний ефект, то вона утворює полюс зростання.

Ж. Бурвіль [3; 4] розглядав теорію полюсів зростання в контексті конкретного географрічного простору. Він показав, що в якості полюсів зростання можна розглядати не тільки підприємства та лідируючі галузі, але і конкретні території [3]. За його переконанням, полюс зростання можна трактувати як географрічну агломерацію економічної активності, яка зосереджена в окремих містах, в яких фрункціонує комплек пропульсивних галузей (виробництв, що інтенсивно розвиваються і розширюються), здатних викликати подальший розвиток економічної діяльності у всій зоні свого впливу [4]. Ж. Будвіль об'єднав простір і фрункцію загальною властивістю - полярністю. Він вважає, що не кожен регіональний центр може бути полюсом зростання, а тільки той центр, в якому $є$ пропульсивно лідируючі галузі, який здатний до самостійного розвитку протягом тривалого часу, контролює своє оточення та інфрормує йому імпульси розвитку.

Розглядаючи полюси економічного росту, $\mathrm{X}$. Ласуен [5] наголошує, що: полюсом росту може бути не просто провідна галузь чи підприємство, а регіональний комплекс підприємств, які фрормують експорт регіону; вся система полюсів зростання i, зокрема, кожен із цих полюсів зростають за рахунок імпульсів, що фрормуються завдяки загальнонаціональному попиту, який, в свою чергу, фрормує експортний сектор регіону; імпульс росту передається іншим другорядним галузям, та іншим територіям, через ринкові зв'язки підприємств.

Подальшого розвитку теорія полюсів зростання набула в роботах П. Поттьє [6], який вважав, що розташування території, яка розміщена між окремими полюсами росту та забезпечення нею їх транспортного зв'язку, сприяє отриманням цією територією додаткових імпульсів зростання, зокрема завдяки збільшенню вантажопотоків, поширенню інновації, розвитку місцевої інфрраструктури. Сукупність сорормованих таким чином полюсів та осей зростання, які з'єднують ці полюси, утворюють просторову основу економічного зростання як регіону так і держави.

Отже, існують різні точки зору щодо теоретичних засад полюсів зростання, але основою концепції полюсів зростання $€$ визначення провідної ролі лідируючих галузей економіки. Проте, незважаючи на багатогранність наукових досліджень в цій ссрері, на сьогодні залишається невирішеними ряд теоретичних і методологічних проблем, які пов'язані з неоднозначністю визначення ролі точок економічного зростання в розвитку територій. Зокрема, відсутній загальноприйнятий інструментарій оцінки рівня розвитку територій з позиції виявлення в них точок економічного зростання, що $€$ методичним базисом для розробки обґрунтованих управлінських рішень місцевих органів влади.

Виклад матеріалу дослідження. Узагальнення різних теоретичних підходів до фрормування та розвитку точок економічного зростання дозволяє констатувати, що рівень розвитку територій визначається рівнем розвитку точок та/або полюсів зростання і силою імпульсу, який передається від пропульсивних галузей економіки другорядним галузям, від територій, які генерують точки зростання до інших територій.

Розглядаючи територіальні точки зростання, необхідно звернути увагу на соціально-економічний розвиток територій країни для яких характерні територіальні диспропорції. Переважна більшість населення, транспортних мереж та виробничих потужностей України концентрується в адміністративних центрах і в прилеглих до них територіях, в той час як для інших територій країни характерними $€$ незадовільний технічний стан транспортних коридорів, зношеність інфрраструктури, неоптимальна система розміщення населення [7]. В результаті чого значна частина ресурсів таких територій залишається неосвоєною або використовується великими компаніями, які переважно також концентрується в адміністративних центрах. В результаті чого місцевий бюджет втрачає потенційні податкові надходження.

Можна виокремити наступні види територіальних точок зростання:

- точки зростання державного рівня, до яких відносяться, перш за все, адміністративні та регіональні центри. Для розвитку системи територіальних точок зростання доцільно використовувати політику стримування росту таких точок державного рівня, перенесення підприємств непрофрільних галузей за їх межі, передачі окремих інфрраструктурних фрункцій іншим точкам економічного зростання;

- точки зростання міжрегіонального значення, які об'єднують міста з міжгалузевими 
комплексами, що обслуговують великі підприємства адміністративних та регіональних центрів. Для стимулювання розвитку системи міжрегіональних точок економічного зростання передбачається в таких містах створення підприємств та галузей, орієнтованих на задоволення потреб населення. Активізація розвитку точок економічного зростання міжрегіонального значення сприятиме тяжінню до них інших точок економічного зростання, появи інноваційних імпульсів між такими точками економічного зростання, максимально еоективному використанню місцевих ресурсів;

- точки економічного зростання внутрішньо регіонального значення. До них відносяться адміністративні центри територіальних фрормувань, значимість та основні фрункції яких визначаються зоною впливу на них міжрегіональних точок зростання.

Окреслимо основні проблеми активізаціі територіальних «точок зростання».

Найчастіше успішність реалізації фрорм активізації точок зростання залежить від умов, в яких ця реалізація проводиться. Так налагоджена інфраструктура необхідна для створення кластерів і технопарків, висока концентрація фрінансових потоків для кластерів і зон освоєння високотехнологічних виробництв, які успішно формуються в регіонах, які мають можливість залучення значних інвестиційних ресурсів. У той час як більшість регіонів країни не мають перерахованих вище умов і, як наслідок, не можуть за допомогою наявних механізмів регіонального управління успішно реалізовувати різні фрорми активізації точок зростання.

Крім того, фракторами, які стримують ефективну реалізацію фрорм активізації точок зростання можуть бути наступні:

- регуляторні: відсутність необхідних регуляторних актів для активізації територіальних точок зростання;

- організаційні: неефективна інфрраструктура, та неефективне використання фрорм активізації територіальних точок зростання (відсутність взаємодії між новоствореними підприємствами регіону для створення імпульсів в фрормуванні територіальних точок зростання і підприємствами регіону які традиційно функціонують, недостатньо повне використання підприємствами ресурсів регіону;

- соціальні: відсутність умов для підвищення економічної активності населення, відсутність соціальної орієнтованості роз- витку територій, недостатні можливості для фрінансування соціальної сфрери регіону (низький рівень соціального забезпечення населення, відсутність можливостей для зростання зайнятості та зростання доходів населення);

- фрінансові: низькі можливості для розширення джерел фрінансування, відсутність необхідних фрінансових потоків (недостатній рівень власних доходів і зростання витрат місцевих бюджетів, зниження стійкості і структурної диверсифікації місцевої економіки);

- інвестиційні: незначна інвестиційна привабливість територій (наявність в ряді територій застарілих виробничих фрондів підприємств, відсутність необхідних технологічних, транспортних ресурсів, відсутність налагодженої місцевої інорраструктури);

- інноваційні: відсутність дієвих механізмів до стимулювання розвитку сорери інновацій.

- екологічні: відсутність потенційних можливостей для зниження негативного впливу на навколишнє природне середовище.

Виявлені групи фракторів, які стримують ефрективну реалізацію форм активізації точок зростання можливо використовувати при дослідженні резервів реалізації різних фрорм активізації таких точок зростання.

Розглядаючи проблеми активізації територіальних точок економічного зростання необхідно розглянути існуючі фрорми реалізації полюсів зростання та особливості формування самих точок економічного зростання в Україні. Територіальний і економічний простір країни досить поляризований і фрактично є своєрідною системою полюсів зростання.

Крім того, в країні є значна кількість депресивних регіонів і тому поляризація просторового розвитку унеможливлює рівне забезпечення населення благами i послугами незалежно від їх місця проживання, що, в свою чергу, призводить до появи соціальної напруженості. Вирівнювання розвитку регіонів за допомогою трансфертної політики втратило свою ефективність через відсутність довгострокового ефекту від її реалізації. Невідповідність в темпах розвитку територій продовжує зростати, що можна розглядати як об'єктивну ринкову тенденцію, тобто по суті відбувається лише вирівнювання бюджетних витрат в розрахунку на душу населення, але не вирівнювання соціально-економічного розвитку регіонів.

Так, економічний розвиток територій в Україні протягом останніх років характеризується 
диспропорційністю та зосередженням виробничого, фрінансового, а також інвестиційного і трудового потенціалу в незначній кількості регіонів. Макроекономічне зростання в Україні після 2000 р. не мало позитивного впливу на зниження регіональних диспропорцій та характеризувалося концентрацією економічного потенціалу в кількох найпотужніших регіонах [8; 9]. Протягом 2000-2012 років у п'яти регіонах (в м. Київ, Донецькій, Дніпропетровській, Одеській, Харківській областях) формувалося більше половини валового регіонального продукту, тоді як на їх території проживало лише 34 \% населення країни.

Подальша концентрація валового регіонального продукту відбувалась лише в м. Києві. Так, якщо у 2000 р. частка валової доданої вартості, сорормованої у м. Києві, становила 11,4\%, у 2012 р. вона зросла до $19,8 \%$, а в 2019 р. - до 23,9\%. Така ситуація $€$ значним прорахунком сфрормованої системи управління регіональним розвитком, оскільки вона не створює умов для стійкого економічного розвитку більшості територій країни.

Водночас зменшилася частка валової доданої вартості в Донецькій (з 12,5\% у 2000 р. до $11,2 \%$ у 2012 р., та до $5,2 \%$ у 2019 р.), Запорізькій (з 5,5\% у 2000 р. до 3,9\% у 2019 р.), Луганській (з 4,6 до 1,1\%), Сумській (з 2,5 до 1,9\%), Одеській (з 5,1 до 4,9\%), Чернігівській (з 2,2 до 2,0\%). Економіка деяких регіонів базується на одній - двох галузях, підприємства яких виробляють проміжну або низькотехнологічну продукцію, що знижує рівень їх конкурентоспроможності на зовнішньому ринку [8].

Регіони країни відчувають значну нестачу інвестиційного ресурсу для ефрективного економічного розвитку. Обсяги прямих іноземних інвестицій, які інвестуються в економіку країни, $€$ незначними. В такому випадку, пріоритетом регіональної економічної політики держави має стати орієнтація на стимулювання точок зростання у всіх регіонах.

Серед фрорм, які сприяють фрормуванню точок зростання, можна виокремити такі, як: територіально-виробничі комплекси; кластери; технопарки; зони техніко-економічного освоєння; малі індустріальні фрормування; зони освоєння високотехнологічного виробництва.

Цікавим $€$ досвід світової практики застосування багаторівневого принципу фрормування регіонів [10], який можна використати для активізації як точок так і полюсів зростання. Зокрема, перший рівень - це економічні райони, що фрормуються за принципом економічної єдності господарства, розташованого на певній території, яка розглядається як господарський комплекс, що фрункціонує в цілісному режимі з урахуванням специфічних місцевих умов [11, с. 103]. До другого рівня відносіть «вузлові» регіони в складі економічних районів, які утворюються за принципом визначення меж моноцентричних агломерацій великих міст та входять до складу економічного району. Їх цілісність зумовлюється внутрішніми тенденціями тяжіння до певного центру - «вузла», яким є домінуючі міста (центри агломерацій), що концентрують потоки людей, товарів, напрямки транспортних комунікацій [11, с. 104], руху транспорту тощо і $€$ полюсами росту. Третій рівень - це території, які формуються за принципом визначення меж моноцентричних агломерацій міст районного значення.

В Україні характерними точками зростання можуть бути промислові вузли, якими можна назвати територіально-виробничі комплекси, що створюють технологічний ланцюг разом 3 об'єктами інфрраструктури.

Тому можна розглянути можливість перетворення сучасних територіально-виробничих комплексів в економічні райони, для чого, в свою чергу, необхідно розглянути їх економічні характеристики: ступінь замкнутості економічних зв'язків всередині таких комплексів; їх структурну організацію (промислові вузли, промислова інсрраструктура і сільськогосподарські підприємства); наявність локальних фрункціональних елементів територіально-виробничих комплексів (промислові і агропромислові комбінати, загальні сировинні бази тощо); характер територіального розташування елементів цих комплексів (концентрований або розосереджений); характер економічних зв'язків між елементами комплексів, що виходить 3 участі підприємств в загальному виробничому циклі, використання природних ресурсів і умов конкретної території.

Ефективність діяльності територіальновиробничих комплексів визначається стійкістю економічних зв'язків, зменшенням транспортних витрат, раціональним використанням місцевих ресурсів, поєднанням територіального і галузевого планування та управління. Ефрективна діяльність територіально-виробничих комплексів позитивно впливає на соціальноекономічний розвиток територій: фрормується інфрраструктура, залучаються інвестори, створюються прогресивні територіальні структури і робочі місця для місцевого населення, зростають доходи місцевих бюджетів. 
Незважаючи на зношеність потужностей сучасних територіально-виробничих комплексів, не слід повністю відмовлятися від самої ідеї їх ефрективного використання для фрормування потенційних точок зростання, яка може бути успішно реалізованою на окремих територіях при модернізації таких комплексів, фрормуванні ефрективних систем управління ними, розвитку галузевої структури і адаптації існуючих територіально-виробничих комплексів до сучасних умов.

Іншою фрормою точок зростання можуть бути кластери, які сьогодні $€$ одиним 3 найбільш прогресивних видів організації господарської діяльності в регіоні. Кластери дають можливість сконцентрувати в одному центрі підприємства різного профрілю, а також кваліфріковані кадри та інфрраструктурні інститути. Кластерні фрормування позитивно впливають, як на конкурентоспроможність конкретних регіонів, так і окремих галузей економіки. При цьому, при розвитку кластерної концепції основною метою $є$ формування підприємств, привабливих для імплантації приватної ініціативи в сореру досліджень і розробок, конкурентоспроможних 3 позиції міжнародного поділу праці, і в той же час необхідно забезпечити есрективне вирішення територіальних і соціальних проблем.

Порівняльний аналіз основних принципів організації діяльності кластерів і територіально-виробничих комплексів, показує, що організація фрункціонування кластерів схожа 3 організацією фрункціонування територіальновиробничих комплексів; як кластерна концепція, так і концепція територіально-виробничих комплексів може бути практично реалізована в адекватних економічних умовах; обидві ці форми територіальної організації виробництва формувалися в специфрічних економічних умовах. Перші кластери і технопарки формувалися природним шляхом як форми есрективної організації інноваційного виробництва, що з позиції держави зробило їх стратегічним інструментом локального впливу, головним призначенням яких $€$ локалізація точок зростання. При цьому під локалізацією розуміється не тільки будь-які геограсрічно вигідні місця для розташування на них виробництва, але ще і виокремлення найбільш пріоритетних соціально-економічних напрямків розвитку територій.

Важливу роль в інноваційному розвитку країни відіграють технопарки як своєрідні точки росту. Розвиток технопарку реалізується в створенні інноваційних підприємств на базі технопарку. На першій стадії фрормується інкубаційний простір для новостворюваних підприємств. На другій стадії фрормується простір, який згодом займають підприємства, що вийшли з інкубатора. На третій стадії створюється простір для інноваційних підприємств.

Попередниками сучасних технопарків були радянські академмістечка, що почали створюватися в 1960-х роках, займалися науководослідними розробками і доводили їх до стадії впровадження у виробничий процес. В Україні на сьогодні створена система технологічних парків, фрормування якої розпочалося у 2000 р. реєстрацією таких технологічних парків як Харківський технопарк «Інститут монокристалів», та технопарк «Інститут електрозварювання ім. Є.О. Патона» в м. Києві. Харківський технопарк «Інститут монокристалів» створено на базі найбільшого в СНД центру з розробки, дослідження і застосування фуннціональних матеріалів, що $€$ основою електронної, лазерної, сцинтиляційної, інсрормаційної, медичної та інших новітніх областей сучасної техніки [12].

Технопарк «Інститут електрозварювання ім. Є.О. Патона» також створений 2000 р. на базі науково-технологічного комплексу НАН України в Києві. Пріоритетними напрями його діяльності $\epsilon$ сучасні енергоефективні і ресурсозберігаючі технології, устаткування і конструкції; спеціальна електрометалургія, технології, механізми і засоби нової техніки в ракетно-космічній і авіаційній областях, в суднобудуванні, залізничному і морському транспорті; грунтообробна і прибиральна техніка; зварювальні і споріднені процеси при будівництві, експлуатації і реконструкції доріг, мостів і транспортних систем [12].

Більшість технопарків було зареєстровано на території м. Київ, зокрема технопарки: «Напівпровідникові технології і матеріали, оптоелектроніка і сенсорна техніка» створений в 2001 р. на базі Інституту фрізики напівпровідників НАН України, «Інститут технічної теплофрізики», «Київська політехніка», «Укрінфротех», «Інтелектуальні інформаційні технології». Згодом створювалися також технопарки регіонального рівня: «Яворів» (Львівська область), Текстиль» (м. Херсон), «Машинобудівні технології» (м. Дніпропетровськ).

Можна виокремити наступні види технопарків:

- університетські технопарки, які $€$ найбільш поширеним їх видом; 
- регіональні галузеві технопарки, які надають такі послуги, як юридичне і бізнесконсультування, організація аутсорсингу між великими і малими підприємствами, консультаційний супровід з впровадження нових технологій як у виробництві промислових підприємствах так і для оптимізації технологічних задач корпорацій; технопарки індустріального типу передбачають створення інорраструктури для розміщення виробничих підприємств і проведення для них консультацій 3 різних сорер діяльності;

- мережеві технопарки організовуються для зосередження напрацювань різних дослідницьких центрів, розташованих на різних територіях;

- технопарки на базі науково-виробничих комплексів - фрормуються на базі місцевих територіальних формувань, на території яких розташовані науково-виробничі комплекси;

Успішній реалізації ідеї технопарків перешкоджають такі обмеження:

- законодавчі (не в повній мірі опрацьовані питання, що стосуються захисту інтелектуальної власності);

- кадрові (наявність обмеженої кількості кваліфрікованих кадрів);

- фрінансові (обмежений обсяг фрінансових ресурсів, непривабливість технопарків для інвесторів);

- непрозорість діяльності технопарків.

Як точки зростання часто розглядаються агломерації. Включення ряду монопрофрільних міст, де головну економічну роль відіграють містоутворюючі підприємства в агломераційний процес дозволить підвищити конкурентоспроможність регіональної продукції, залучити додаткові інвестиції та стабілізувати міграційні процеси, що в цілому позитивно відобразиться на соціально-економічному розвитку регіону.

Передумовами створення агломерацій $\epsilon$ : збільшення житлового будівництва, розширення приміських зон проживання, наявність необхідної інфрраструктури, зростання робочих місць, наявність єдиного інфрормаційного простору.

До проблем, які перешкоджають агломераційним процесам, належать відмінності в якості життя великих та малих міст, нерегулярне транспортне сполучення, неопрацьованість перспектив розвитку територіальних громад. До можливих негативних ефектів агломераційних процесів відносять зростання соціальної диференціації, посилення екологічних проблем, виникнення конорлікту між владними структурами центру і периорерії.
Слід зазначити, що точка економічного зростання регіону може бути складовою частиною, або окремим випадком полюса економічного розвитку. Підставою створення точок зростання $€$ поява джерела інноваційного розвитку в будьякій сорері і в можливості апробації цих інновацій на обмеженій території. Точки економічного зростання, які генеруються для розвитку територіальних фоомувань повинні сприяти підвищенню рівня життя населення, яке проживає на цій території і сприяти зростанню зайнятості, зростанню доходів місцевого бюджету, розвитку економічної діяльності, бути мультиплікатором економічного зростання, підвищенню стійкості і структурної диверсифікації місцевої економіки, зниженню негативного впливу на навколишнє природне середовище, орормуванню обраного іміджу і перспективної спеціалізації.

За результатами проведеного аналізу можна зробити висновок, що стратегічний підхід до соціально-економічного розвитку територій регіону передбачає виявлення таких вимог до точок економічного зростання: наявність необхідних інтелектуальних, освітніх, технологічних, транспортних ресурсів, що забезпечують реалізацію стратегії регіону, яка націлена на зміну не тільки кількісних, а й якісних характеристик економіки регіону.

В процесі генерування нових точок економічного зростання в територіальних фрормуваннях регіону необхідним є дотримання наступних критеріальних вимог: еорективності, комплексності та соціальної орієнтованості, що дозволить забезпечити збалансований розвиток економіки регіону.

Критерій ефрективності є основним при генеруванні точок економічного зростання, оскільки використання будь-яких чинників виробництва і відповідно наявного ресурсного потенціалу, має забезпечувати максимальну віддачу на одиницю задіяних ресурсів.

Соціальна орієнтованість точок економічного зростання проявляється в покращенні таких показників, як тривалість та якість життя і стан громадського здоров'я населення території.

У сучасних умовах, перераховані і обґрунтовані вище критеріальні вимоги необхідно доповнити вимогою комплексного та інноваційного розвитку. При розвитку регіону часто акцент робиться на розвиток промисловості, яка є структуроутворюючим ядром регіональної економіки, в той час саме на інноваційній основі повинні розвиватися всі ссрери життєдіяльності регіону.

Основою виявлення та активізації точок економічного зростання в регіоні, $є$ алгоритмічний опис його організаційно-методичного 


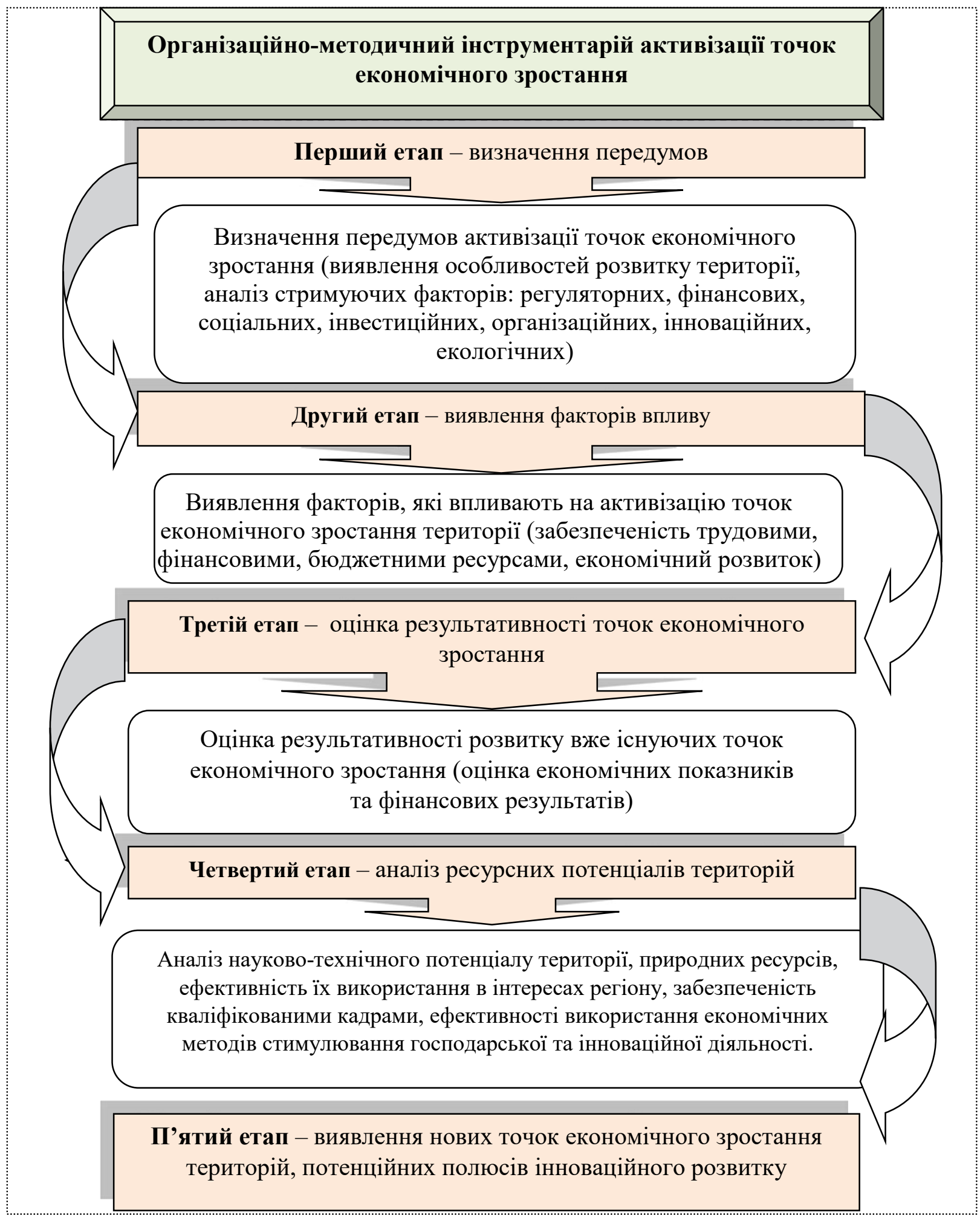

Рис. 1. Алгоритм організаційно-методичного інструментарію активізації точок економічного зростання

Джерело: розроблено автором

інструментарію Пропонуємо авторську розробку алгоритму організаційно-методичного інструментарію активізації точок економічного зростання (рис. 1).
Висновки. Розгляд різних форм реалізації теорії полюсів зростання і умов формування точок зростання дозволив виявити основні групи фракторів, які стримують есрек- 
тивну реалізацію фрорм активізації точок зростання: регуляторні (відсутність необхідних регуляторних актів для активізації територіальних точок зростання); організаційні (неефективна інфрраструктура, та неефективне використання фрорм активізації територіальних точок зростання: відсутність взаємодії між новоствореними підприємствами регіону для створення імпульсів в орормуванні територіальних точок зростання і підприємствами регіону які традиційно фрункціонують, недостатньо повне використання підприємствами ресурсів регіону); соціальні: відсутність умов для підвищення економічної активності населення, відсутність соціальної орієнтованості розвитку територій, недостатні можливості для фрінансування соціальної ссрери регіону (низький рівень соціального забезпечення населення, відсутність можливостей для зростання зайнятості та зростання доходів населення); фрінансові: низькі можливості для розширення джерел фрінансування, відсутність необхідних значних фрінансових потоків (недостатній рівень власних доходів і зростання витрат місцевих бюджетів, зниження стійкості і структурної диверсифрікації місцевої економіки); інвестиційні: незначна інвестиційна привабливість територій (наявність в ряді територій застарілих виробничих фрондів підприємств, відсутність необхідних технологічних, транспортних ресурсів, відсутність налагодженої місцевої інфрраструктури); інноваційні: відсутність дієвих механізмів до стимулювання розвитку сорери інновацій; екологічні: відсутність потенційних можливостей для зниження негативного впливу на навколишнє природне середовище.

Запропоновано алгоритм організаційнометодичного інструментарію активізації точок економічного зростання, який включає ряд етапів, розглянемо окремі змістовні особливості цих етапів. Першочерговим етапом $€$ визначення передумов активізації точок економічного зростання (виявлення особливостей розвитку території, аналіз стримуючих фракторів: регуляторних, фрінансових, соціальних, інвестиційних, організаційних, інноваційних, екологічних). Наступним етапом $€$ виявлення фракторів, які впливають на активізацію точок економічного зростання території (забезпеченість трудовими, орінансовими, бюджетними ресурсами, есрективність економічного розвитку). На третьому етапі здійснюється оцінка результативності розвитку вже існуючих точок економічного зростання (оцінка економічних показників та фрінансових результатів). Аналіз ресурсних потенціалів територій (аналіз науково-технічного потенціалу території, природних ресурсів, ефективність їх використання в інтересах регіону, забезпеченість кваліфрікованими кадрами, ефективності використання економічних методів стимулювання господарської та інноваційної діяльності) - завдання четвертого етапу активізації точок економічного зростання. На наступному етапі виникає необхідність виявлення нових точок економічного зростання територій, потенційних полюсів інноваційного розвитку.

Наведений алгоритм організаційно-методичного інструментарію активізації точок економічного зростання дозволить активізувати процеси забезпечення стійкого економічного розвитку територій.

Перспективи подальших досліджень. В останні роки все більша увага приділяється не тільки ефективності розвитку різних галузей економіки в регіоні та підвищення рівня добробуту громадян, а й оцінці взаємозв'язку цих процесів. Зокрема, вирішення цього питання розглядається через реалізацію структурно-територіальної економічної політики, шляхом вирішення проблеми відповідності структури виробництва структурі розміщення ресурсів, а також реалізації кластерного підходу в соціально-економічному розвитку територій регіону. Оскільки однакових регіонів не існує, то і немає однакових управлінських рішень, тому часто оптимальним можна вважати поєднання різних підходів, що базується на виявленні економічного потенціалу регіону, ресурсної забезпеченості та взаємозв'язків між видами економічної діяльності для виокремлення точок економічного зростання. Активізація регіональних точок зростання дозволить підвищити ефективність організації регіонального управління, ефективність використання фрінансових ресурсів і сконцентрувати регіональні ресурси на пріоритетних напрямках. Подальшого вивчення потребує пошук ефрективних способів активізації регіональних точок зростання, дослідження критеріїв відбору територій, придатних для проведення політики активізації точок зростання, розробка механізму взаємодії органів державної влади та місцевого самоврядування щодо активізації територіальних точок зростання. 


\section{СПИСОК ВИКОРИСТАНИХ ДЖЕРЕЛ:}

1. L'Économie du XXe siècle: par François Perroux. Presses universitaires de France (Vendôme, Impr. des P.U.F.), 1961. 599 p.

2. Perroux F. Note sur la notion de poles croissance (Translated by Mette Monsted, 1974). Economic Appliquee. 1955. Vol. 1, 2. P. 307-320.

3. Boudeville J. R. Les 'espace economique. Paris : PUF, 1961. P. 16-37.

4. Boudeville J.-R. Problems of Regional Economic Planning. Edinburg, Edinburgh University Press. 1966. P. 9-128.

5. Lasuen J. On Growth Poles. Urban Studies. 1969. Vol. 6. No. 2. P. 137-161.

6. Pottier P. Axes de communication et developpement economique. Revue Economique. 1963. Vol. 14. P. 58-132.

7. Ліщинський І. Нова економічна географрія та альтернативні концепції агломерації виробництва. Журнал європейської економіки. 2009. № 3. С. 241-264.

8. Державна Стратегія регіонального розвитку на період до 2020 року : Постанова Кабінету Міністрів України від 6 серпня 2014 р. № 385. URL: https://zakon.rada.gov.ua/laws/show/385-2014-\%D0\%BF/print 1446542150663211\#n11 (дата звернення: 12.04.2021).

9. Про затвердження Державної стратегії регіонального розвитку на 2021-2027 роки : Постанова Кабінету Міністрів України від 5 серпня 2020 р. № 695. URL: https://zakon.rada.gov.ua/laws/show/695-2020-\%D0\%BF\#Text (дата звернення: 12.04.2021).

10. Невелєв О. Упорядкування адміністративно-територіального устрою та вдосконалення системи місцевого самоврядування в Україні. Економічний Часопис-XXI. 2004. № 1. URL: http://www.soskin.info/ea.php ?pokazold=20040103\&n=1\&y=2004 (дата звернення: 12.04.2021).

11. Бондарук Т.Г. Місцеве самоврядування та його фрінансове забезпечення в Україні : [моногр.] ; НАН України ; Ін-т екон. та прогнозув. Київ : Експрес, 2009. С. 103-104.

12. Технологічні парки. Міністерство освіти і науки України. URL: https://mon.gov.ua/ua/nauka/innovacijnadiyalnist-ta-transfer-tehnologij/tehnologichni-parki (дата звернення: 12.04.2021).

\section{REFERENCES:}

1. L'Économie du XXe siècle: par François Perroux (1961). Presses universitaires de France (Vendôme, Impr. des P.U.F.), 599.

2. Perroux F. (1955). Note sur la notion de poles croissance (Translated by Mette Monsted, 1974). Economic Appliquee, 1, 2, 307-320.

3. Boudeville J.R. (1961). Les 'espace economique. Paris: PUF, 16-37.

4. Boudeville J.R. (1966). Problems of Regional Economic Planning. Edinburg, Edinburgh University Press, 9-128.

5. Lasuen J. (1969). On Growth Poles. Urban Studies, vol. 6. 2, 137-161.

6. Pottier P. (1963). Axes de communication et developpement economique. Revue Economique, 14, 58-132.

7. Lishchyns'kyy I. (2009). Nova ekonomichna heohrafiya ta al'ternatyvni kontseptsiyi ahlomeratsiyi vyrobnytstva. [New economic geography and alternative concepts of agglomeration of production]. Zhurnal yevropeys'koyi ekonomiky, 3, 241-264. (in Ukrainian)

8. Derzhavna Stratehiya rehional'noho rozvytku na period do 2020 roku [State Strategy for Regional Development until 2020]: Postanova Kabinetu Ministriv Ukrayiny vid 6 serpnya 2014 r. no. 385. URL: https://zakon.rada.gov.ua/ laws/show/385-2014-\%D0\%BF/print1446542150663211\#n11 (accessed 12 April 2021). (in Ukrainian)

9. Pro zatverdzhennya Derzhavnoyi stratehiyi rehional'noho rozvytku na 2021-2027 roky: Postanova Kabinetu Ministriv Ukrayiny vid 5 serpnya 2020 r. no. 695 [On approval of the State Strategy for Regional Development for 2021-2027]. URL: https://zakon.rada.gov.ua/laws/show/695-2020-\%D0\%BF\#Text (accessed 12 April 2021). (in Ukrainian)

10. Nevelyev O. (2004). Uporyadkuvannya administratyvno-terytorial'noho ustroyu ta vdoskonalennya systemy mistsevoho samovryaduvannya $v$ Ukrayini [Streamlining the administrative-territorial system and improving the system of local self-government in Ukraine]. Ekonomichnyy Chasopys-XXI, 1. URL: http://www.soskin.info/ea.php?pokazold=20040103\&n=1\&y=2004 (accessed 12 April 2021). (in Ukrainian)

11. Bondaruk T. H. (2009). Mistseve samovryaduvannya ta yoho finansove zabezpechennya v Ukrayini [Local self-government and its financial support in Ukraine]. [monohr.]; NAN Ukrayiny; In-t ekon. ta prohnozuv. Kyiv: Ekspres, pp. 103-104.

12. Tekhnolohichni parky [Technology parks]. Ministerstvo osvity i nauky Ukrayiny. URL: https://mon.gov.ua/ua/ nauka/innovacijna-diyalnist-ta-transfer-tehnologij/tehnologichni-parki (accessed 12 April 2021). (in Ukrainian) 